\title{
Association between the Education and Thalassaemia: A Statistical Study
}

\author{
Qamruz Zaman \\ Department of Medical Statistics \\ Informatics and Health Economics, \\ Innsbruck Medical University, Austria \\ Salahuddin \\ Department of Statistics \\ University of Peshawar \\ Peshawar, NWFP, Pakistan
}

\begin{abstract}
This article comprises the questionnaire/interview survey of 320 patients and their parent's conducted in Peshawar, Pakistan to study the literacy of thalassaemia among parents and the severity of thalassaemia on different social aspects. Parent's educations were strongly linked to cure that disease specially the test (during pregnancy). The majority of parent's were illiterate and were also against the family planning. Inter family marriages was also one of the main reason of the disease among these patient's. $56.9 \%$ of the patient parents were first cousins while only $1.3 \%$ of the patients were matriculate. In the social factors, their average family income was very less as compared to the family members and the expenditure of the treatment. It was also found that the disease was more common in positive blood groups. To coup with the situation, efforts to increase the literacy rate and awareness of the disease are urgently required.
\end{abstract}

\section{Introduction}

Thalassaemia genes are remarkably widespread, and are believed to be most prevalent of all human genetic disease. Thalassaemia is an inherited disorder in which there is an abnormality in one or more of the globin genes (Hong, 2000). In general thalassaemia can be sub-divided into two groups: $\alpha$-thalassaemia and $\beta$ thalassaemia. In the former, people whose haemoglobin does not produce enough alpha protein have $\alpha$-thalassemia. It is commonly found in Africa, the Middle East, and Southeast Asia. While in the latter, people whose haemoglobin does not produce enough beta protein have $\beta$-thalassemia. It is found in peoples of Iran, Pakistan, Afghanistan and Southern China. Like $\alpha$-thalassemia, $\beta$ thalassaemia ranges from mild to severe in their effect on the body: Thalassaemia minor, Thalassaemia intermediate and Thalassaemia major. Thalassemia Major is also called Cooley's Anaemia, Homozygous $\beta$ thalassaemia, Homozygous thalassaemia or Mediterranean anaemia (Rino, et. al., 1995).

Bird et. al. (1987) presented the findings of a survey to determine the prevalence of inherited haemoglobin disorders in mixed ethnic origin population of South Africa. The alpha+ thalassaemia haplotype was particularly common. Betathalassaemia was rather less common. 
$\beta$-thalassaemia major is more sever in Pakistan and this research is also based on it. This is the most severe form of $\beta$-thalassaemia in which the complete lack of beta protein in the haemoglobin causes a life-threatening anaemia that requires regular blood transfusions and extensive ongoing medical care. Thalassaemia has been initiated its web all over Pakistan since 1947 and out of every 100 Pakistanis, six are carriers of the thalassaemia gene. Fatimid Foundation, a non-profit charitable organization is the pioneer of voluntary blood transfusion services, has been started in Pakistan in 1981. Foundation has grown into the largest organization of its kind in the country. Its four centres in Pakistan are Peshawar, Karachi, Lahore and Multan centres, staffed by a professional team of physicians and trained workers (Fatimid, 1981, Thalassaemia, 1995).

The country first regular prenatal diagnostic service for thalassaemia has been started in 1994 (Ahmed et al., 1994). Although the disease is not very new in the country, but until now a very few studies have been conducted on it. But still nobody wrote anything about social aspects and the family background of the patient. According to our literature survey, this is first study, which is conducted in this respect and also it is the first study in which people of two countries Pakistan and Afghanistan are considered. This study aimed to provide the knowledge and awareness to the people, about the general things, so that, they will be able to understand the severity of the disease and the ways to protect the new generation from the disease.

\section{Methodology}

The study of 320 patients and their parent's was conducted between November 2002 and April 2003, in Fatimid Foundation Peshawar, Pakistan. The questionnaire and interview were designed to collect information on different aspects. The information was collected not in fixed timing of the day, but it changed from day to day in order to collect the every kind of information from different status of people. The employed people would like to visit their children to the foundation in fewer rush hours, while the other people from the city reached the centre early morning. This sample also includes the patients who visit to the centre from other parts of the province. Since the city is located at the boarder of Afghanistan. We also got a chance to collect the data from various afghan people lived in Peshawar or just came to visited the foundation. They were also included in these 320 patients. The questionnaire interview was designed to collect information on the number of aspects, especially on the basic knowledge of the patient parent's about the disease.

The questionnaire and interview were mainly consisted of ten questions, relating to sex of the patient, relation of the patient parents, education of the patient, father income, blood group of patient, family members, parent's education, parent's knowledge about the test, parent's can afford the (during pregnancy) test, parent's tendency towards family planning. 
Response to structured questions was entered and analysed using SPSS, version 11.5 .

\section{Results}

The data were taken from 320 patients out of these 191 were male and 129 were female i.e. in terms of percentage $60 \%$ male patients and $40 \%$ female patients were observed.

Table (1) summarizes the response of the questions. The majority of patient parents were first cousins and $19.4 \%$ of the patient parents were also relative, while it was also found in the unknown parents who were not relative to each other. Half of the patient family members lies between 5 to 7 and was large in number. $33.1 \%$ of the patients belonged to the families whose family size were less than or equal to 4 , while it was only $3.2 \%$ in the family range of 11 to 13 .

The positive blood groups patients were in majority. $32.2 \%$ of the patients possessed A-positive group, and $29.1 \%$ possessed B-positive. On the other hand, $25.3 \%$ were belonged to O-positive and only $0.9 \%$ patients had O-negative group.

From education question, it summarized that majority of patients i.e. $38.8 \%$ never hold the pen in their hands, and $35.3 \%$ of patients had the level, which was below the $5^{\text {th }}$ class, in which those were also included who once took the admission and then after some time left the school, while only $1.2 \%$ of 320 patients were matriculate.

$18.1 \%$ parent's can afford the test during pregnancy, while $81.9 \%$ cannot afford. Due to religion and other constrained, table showed that $29.1 \%$ parents are in favour of family planning while $70.9 \%$ are against of this. Among the 320 patient's, only $21.9 \%$ of their parent's are educated while the rest are uneducated. Moreover, less than $20 \%$ of the parent's were familiar about the test (before the first child).

Table (2) is used to calculate the $\chi^{2}$ for the $2 * 2$ table to check the association between parent's education and the parent's knowledge about thalassaemia. $\chi^{2}$ gave the large value 5.53, which showed that there is association between the education and knowledge of thalassaemia. The two things are related. Similarly, Table (3) summarizes the association between parent's education and their knowledge about the test. Again from the large value of $\chi^{2}=42.73$, we found that the educated parent's have more knowledge about the test as compared to uneducated parents.

The histogram of the father income, shows that 100 patients belonged to the families, whose income was between 2 to 3 thousands rupees, while there were less than 5 patients, whose father income were more than Rs. 6000. 


\section{Discussion}

It has been found that thalassaemia is a blood disease and is common in both sex. Although, in this study, it was seemed to be more common in male than female, which may be due to the fact that in that part of the world, parent's pay more attention to male than to female or which may be occurred due to chance.

The findings are based from the collected data from the patients who visited Fatimid Foundation Peshawar, for blood transfusions, from Peshawar city and other parts of NWFP province as well as nearest areas of Afghanistan. Since there is only one centre of Fatimid Foundation in the province, the collected data is a representative sample of the thalassaemia patients in the province and we can make inferences from the percentages in Table (1) for the whole province.

The majority of the patient parents were first cousins, while it was found that $23.7 \%$ of the patient parent's before marriage were unknown to each other, which showed that it was not only common in the inter family marriages, but it may occurred if the couples belonged to different families to.

In blood group aspects, the results showed that $94.7 \%$ of patient possessed positive blood group and only $5.3 \%$ of the patients had negative group.

While in education aspects; less than $2 \%$ of the patients were matriculates while around $40 \%$ were uneducated. Which may be due to the fact that due to severity of the disease and regular transfusion of blood, it was difficult for them to continue the study. Out of this small sample of patient's, less than $25 \%$ of the patient parent's were educated, which is one of the main reasons to spread of disease. Although, $21.9 \%$ parent's were educated but it is surprising that only $19.7 \%$ parents were familiar about the test, while $18.1 \%$ can afford the during pregnancy test. Another reason to spread of the disease is the war against family planning as $71 \%$ of these patient parents were not in favour of any planning. For the prevention of the disease, educated well-informed parents play the most important role.

The average father (family) income of these patients was Rs. 2376.8, which means Rs 2,8512 per annum and the average yearly expenditure on the patient were Rs. 1,0000[4]. As most of the patient belonged to the poor families, so it was very difficult for them to survive.

According to the study on thalassaemia, different suggestions are recommended to control the disease and its spread in our population. These are as following:

1) General awareness of the people regarding the features and complications of thalassaemia, which can be carried out through different medias like newspaper, television, radio etc.

2) General health education among the people should also be carried out to arrange treatment for those, suffering from thalassaemia, which will help prevention of spread of thalassaemia. 
3) The Hospitals and welfare societies should cooperate with the researchers, because data collection is the biggest problem faced by researchers in Pakistan.

4) Every Hospital should be computerized and there should be proper records of every individual case, so that the analysis based on that data is accurate.

5) Before planning for the solution of a problem first of all the nature and severity of the problem should be completely recognized. Proper registration system of the event under study is considered to be the backbone for the meaningful and satisfactory solution of the problem. For the complete knowledge of the problem the registration system must be improved and for this purpose properly trained persons should be appointed. Hence the need and the role of a 'Statistician' in such areas should be recognized.

6) This is not only the responsibility of foundation and government to control the disease. But it is also the responsibility of every carrier and especially, it is the duty of carrier marriage women to visit the doctors regularly during pregnancy.

7) Necessary medicines, blood and disposable injections should be provided at the Basic Health Units, Centres and free dispensaries should be set.

8) Government should spend more money to provide cheap or free treatment of disease to the population.

9) Most of patient's are living in rural areas, where an easy access to the divisional head quarter hospitals is not possible every time. So it is suggested that there should be a standard children hospital in every subdivision. So that blood and other medicines will be easily available for the peoples of this area.

10) Couples should go for a blood test to test their DNA build up before planning to start a family. In this way, they will be aware of the possible genetic disease that their children may acquire. Genetic counselling will then be able to advise and present the options for the couple to decide on the family they want. Prenatal diagnosis will also be able to detect any deformities or genetic disease of the child. Therefore, knowing that the child has thalassaemia major genes before it is born will help decrease the cases in Pakistan. (It all still depends on the decisions of the couples).

Before we close the topic, it is imperative to mention, that most of our population is illiterate and without proper health education it is impossible for them to know the exact nature of this deadly disease. Further investigation would consider the study of association between blood group and $\beta$-thalassaemia ranges from mild to severe.

\section{Acknowledgement}

The authors would like to thank the referees for their helpful comments leading to the improvements of the paper. 
Table (1): Response of the questionnaire and interview

\begin{tabular}{|c|c|c|}
\hline Response & $\begin{array}{l}\text { No. } \\
N=320\end{array}$ & $\%$ \\
\hline \multicolumn{3}{|l|}{ Sex } \\
\hline Male & 191 & 60 \\
\hline Female & 129 & 40 \\
\hline \multicolumn{3}{|l|}{ Relation of the patient parents } \\
\hline Cousins & 182 & 56.9 \\
\hline Relatives & 62 & 19.4 \\
\hline \multirow{2}{*}{\multicolumn{3}{|c|}{ Blood Groups }} \\
\hline & & \\
\hline A- & 6 & 1.9 \\
\hline A+ & 103 & 32.2 \\
\hline AB- & 1 & 0.3 \\
\hline$A B+$ & 26 & 8.1 \\
\hline B- & 7 & 2.2 \\
\hline$B+$ & 93 & 29.1 \\
\hline O- & 3 & 0.9 \\
\hline $\mathrm{O}+$ & 81 & 25.3 \\
\hline \multicolumn{3}{|l|}{ Family Members } \\
\hline$\leq 4$ & 106 & 33.1 \\
\hline $5 \leq--\leq 7$ & 162 & 50.6 \\
\hline $8 \leq--\leq 10$ & 42 & 13.1 \\
\hline $11 \leq--\leq 13$ & 10 & 3.2 \\
\hline \multicolumn{3}{|l|}{ Education level } \\
\hline Nil & 124 & 38.8 \\
\hline Below Primary & 113 & 35.3 \\
\hline Primary & 61 & 19.1 \\
\hline Middle & 18 & 5.6 \\
\hline Metric & 4 & 1.2 \\
\hline \multicolumn{3}{|l|}{ Parent's are educated } \\
\hline Yes & 70 & 21.9 \\
\hline No. & 250 & 78.1 \\
\hline \multicolumn{3}{|l|}{ Parent's Knowledge about test } \\
\hline Yes & 63 & 19.7 \\
\hline \\
\hline $\begin{array}{l}\text { Pes } \\
\text { Yest }\end{array}$ & 58 & \\
\hline No. & 262 & $\begin{array}{l}18.1 \\
81.9\end{array}$ \\
\hline \multicolumn{3}{|l|}{$\begin{array}{l}\text { Parent's tendency towards family } \\
\text { planning }\end{array}$} \\
\hline Yes & 93 & \\
\hline No. & 227 & $\begin{array}{l}29.1 \\
70.9\end{array}$ \\
\hline
\end{tabular}


Table (2): Educated Parent's and their knowledge about the disease

\begin{tabular}{|l|cc|c|}
\hline Parent's Educated & \multicolumn{2}{|c|}{$\begin{array}{c}\text { Parent's Knowledge about Thalassaemia } \\
\text { Yes }\end{array}$} & No. \\
\cline { 1 - 4 } Yes & 54 & 16 & 70 \\
\cline { 1 - 4 } No. & 155 & 95 & 250 \\
\hline Total & 209 & 111 & 320 \\
\hline
\end{tabular}

$\chi^{2}=5.53$

$\chi_{.05(1)}^{2}=3.84$

Table (3): Educated Parent's and their knowledge about the test

\begin{tabular}{|l|cc|c|}
\hline Parent's Educated & \multicolumn{2}{|c|}{$\begin{array}{c}\text { Parent's Knowledge about The } \\
\text { Pregnancy test (before first birth) } \\
\text { Yes }\end{array}$} & No. \\
\cline { 1 - 4 } Yes & 33 & 37 & 70 \\
\cline { 1 - 4 } No. & 30 & 220 & 250 \\
\hline Total & 63 & 257 & 320 \\
\hline
\end{tabular}

$x^{2}=42.73$

$\chi_{.05(1)}^{2}=3.84$

Figure (1): Father Income of the Patient

Father income

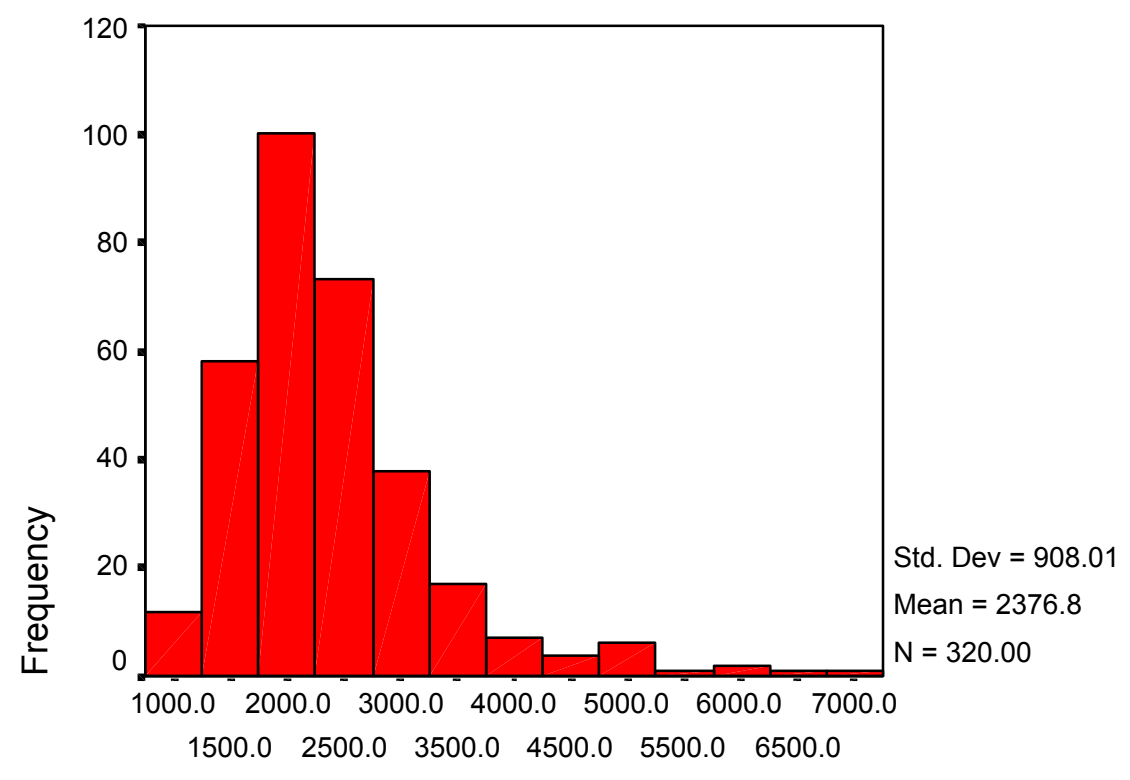

Father income 


\section{References}

1. Ahmed, S.; Saleem, M.; Rashid, Y.; Abbas, N. and Malik, A. (1994). Prenatal diagnosis of Thalassaemia in Pakistan. First case report. Pakistan Journal of Pathology, Vol. 5, No: (1).

2. Bird, A.R.; Ellis, P.; Wood, K.; Mathew, C. and Karabus, C. (1987). Inherited haemoglobin variants in a South African Population. J. Med. GENET. 24(4): 215-219.

3. Fatimid Foundation: A symbol of hope Pakistan, established in 1981.

4. Hong G.R. (2000). Hemoglobin disorders. In: Behrman RE, Kliegman RM, Jenson HB, eds. Nelson textbook of pediatrics, $16^{\text {th }}$ ed. Philadelphia, WB Saznders Company.

5. Rino, V.; Bernadette, M. and Evgentia, G. (1995). What is Thalassaemia? $2^{\text {nd }}$ ed. Thalassaemia International Foundation.

6. Thalassaemia Society of Pakistan, Established in 1995. 